\title{
Letter: embolization of the middle meningeal artery in patients with chronic subdural hematoma-a systematic review and meta-analysis
}

\author{
A. Celal İplikçioğlu ${ }^{1}$ \\ Received: 10 April 2020 / Accepted: 1 May 2020 / Published online: 20 May 2020 \\ (C) Springer-Verlag GmbH Austria, part of Springer Nature 2020
}

\section{Dear Editor,}

I have read the article by Haldrup et al., "Embolization of the middle meningeal artery in patients with chronic subdural hematoma-a systematic review and meta-analysis" [2]. They collected 191 cases from 18 studies and found recurrence rate of $4.1 \%$ for primary cases, while it was $2.4 \%$ for recurrent cases. In 2005, we conducted a study in which 27 cases of unilateral convexity chronic subdural hematoma were treated with burr hole evacuation and closed drainage [1]. In 14 of the cases, ipsilateral middle meningeal artery was surgically ligated or clipped via a temporal burr hole. Drainage duration, total drainage volume, and total protein albumin globulin levels of drainage material were lower in the cases with clipped middle meningeal artery. No recurrence was found in both groups. Nevertheless, the results were not statistically significant, likely due to low number of patients. Lower protein levels suggested that surgical ligation or clipping of the middle meningeal artery was effective in the treatment of chronic subdural hematoma [3,5]. I think surgical middle meningeal artery ligation is a good alternative to embolization and can be performed especially in patients with risk factors for recurrence such as advanced age, midline shift, and mixed density on CT [4].

This article is part of the Topical Collection on Vascular Neurosurgery Other

\section{A. Celal İplikçioğlu}

acelal@doctor.com

1 Department of Neurosurgery, BHT Clinic, Istanbul Tema Hospital, Atakent Mahallesi 4. Cadde No: 36 Küçükçekmece,

34307 Istanbul, Turkey

\section{Compliance with ethical standards}

Conflict of interest The author declares that he has no conflict of interest.

\section{References}

1. Bikmaz K, Iplikcioglu C, Dinc C, Arslan M (2006) Treatment of chronic subdural hematomas by clipping of arteria meningia media. Skull Base 16:A024. https://doi.org/10.1055/s-2006-958291

2. Haldrup M, Ketharanathan B, Debrabant B et al (2020) Embolization of the middle meningeal artery in patients with chronic subdural hematoma - a systematic review and meta-analysis. Acta Neurochir 162:777-784. https://doi.org/10.1007/s00701-020-04266-0

3. İplikçioğlu AC, Berkman MZ, Bek Ș, Șengöz A (2004) Phenytoin penetration into chronic subdural haematomas. Br J Neurosurg 18(1):35-39. https://doi.org/10.1080/02688690410001660436

4. Qian Z, Yang D, Sun F, Sun Z (2017) Risk factors for recurrence of chronic subdural hematoma after burr hole surgery: potential protective role of dexamethasone. Br J Neurosurg 31(1):84-88. https://doi. org/10.1080/02688697.2016.1260686

5. Tokmak M, Iplikcioglu A, Bek S, Gökduman C, Erdal M (2007) The role of exudation in chronic subdural hematomas. J Neurosurg 107(2):290-295. https://doi.org/10.3171/JNS-07/08/0290

Publisher's note Springer Nature remains neutral with regard to jurisdictional claims in published maps and institutional affiliations. 